\title{
JAK PRZEMIESZCZA SIĘ PRÓŻNIA? WĘDRÓWKI TEZY STEFANA NOWAKA MIĘDZY OBSZARAMI I KONTEKSTAMI ${ }^{1}$
}

\author{
Mikołaj Pawlak \\ Uniwersytet Warszawski
}

\section{/// 1. Wprowadzenie}

Teza mówiąca o istnieniu w polskim społeczeństwie próżni socjologicznej to jedno z najbardziej znanych twierdzeń w naszym obiegu socjologicznym. Od końca lat 70. XX wieku, kiedy ogłosił ją Stefan Nowak, do dzisiaj pojęcie „próżni socjologicznej” pojawia się w licznych publikacjach z zakresu nauk społecznych. Przebiło się ono również do dyskursu publicystycznego. Skoro jest to tak ważne pojęcie dla socjologii uprawianej w Polsce, dlaczego nie zostało ono „wyeksportowane” i nie funkcjonuje w socjologii światowej? Zagraniczni autorzy posługują się nim właściwie tylko wtedy, gdy chcą powiedzieć coś o polskim społeczeństwie. Pierwszym celem niniejszego artykułu jest prześledzenie nielicznych wędrówek pojęcia „próżni socjologicznej” poza kontekst polskiego społeczeństwa. Jak zobaczymy, jest ono tak silnie związane z przekonaniem o unikalności pewnych zjawisk społecznych zachodzących w Polsce, iż nie podejmowano prób uogólniania tezy Nowaka w odniesieniu do obszaru poza Europa Wschodnią. Drugim celem jest przeanalizowanie tego, jak wędrówki między kontekstami tematycznymi wpływają na przekształcenia koncepcji

\footnotetext{
${ }^{1}$ Niniejszy artykuł powstał w ramach projektu badawczego „Co wypełnia próżnię socjologiczną? Reinterpretacja tezy Stefana Nowaka z perspektywy sieciowej, na przykładzie zachowań na rynku pracy" dzięki dofinansowaniu Narodowego Centrum Nauki (DEC-2012/07/D/HS6/00977). Chciałbym podziękować Mikołajowi Cześnikowi, Mateuszowi Fałkowskiemu, Ireneuszowi Krzemińskiemu, Kacprowi Wierzbickiemu oraz dwojgu anonimowym recenzentom, których pomoc i sugestie przyczyniły się do napisania tego artykułu.
} 
„próżni socjologicznej”: przesunięcia jej znaczenia i selektywnego odwoływania się do pewnych jej komponentów.

Teza ta ugruntowana jest w paradygmacie badań ankietowych, w którym społeczeństwo analizowane jest jako agregat jednostek przyjmujących pewne wartości, postawy i identyfikacje. Nie można jednak powiedzieć, iż „próżnia socjologiczna” stanowi teorię społeczeństwa polskiego, jest ona twierdzeniem użytym w eseistycznym opisie ważnych - zdaniem Nowaka - cech tego społeczeństwa. Traktuję zatem próżnię socjologiczną jako ideę wykorzystywaną w naukach społecznych do opisu stanu społeczeństwa. Za Barbarą Czarniawską (2010) rozumiem ideę jako dyskursywny opis rzeczywistości, który po dekontekstualizacji, czyli oderwaniu od pewnego konkretnego odniesienia historycznego, może zostać użyty w innym kontekście. Konieczność jej językowego utrwalenia i dostosowania do nowego kontekstu modyfikuje ideę. W odniesieniu do pojęcia „próżni socjologicznej” oznacza to na przykład, iż idea ta użyta przez Nowaka do opisu rozkładu identyfikacji społecznych w Polsce epoki Gierka może zostać następnie wykorzystana przez innego autora do opisu aktywności organizacji trzeciego sektora w Polsce początku XXI wieku lub do opisu warunków powstawania nieformalnych sieci społecznych na Ukrainie.

Artykuł rozpoczynam od przedstawienia tezy Stefana Nowaka. Następnie wskazuję 190 publikacji naukowych przywołujących jego koncepcję. W zasadniczej części tekstu opisuję, jak za pomoca „próżni socjologicznej” spoglądano „z zewnątrz” na polskie społeczeństwo i jak próbowano odnieść to pojęcie do innych społeczeństw; skrótowo porównuję „próżnię socjologiczną" z podobnymi pojęciami (takimi jak: załamywanie się społeczności, społeczeństwo klepsydry, perspektywa braku środka), a następnie omawiam użycia tego terminu w czterech polach tematycznych: Solidarność, społeczeństwo obywatelskie, kapitał społeczny i jakość demokracji. Jak pokazuję w ostatniej części tekstu, pojęcie „próżni socjologicznej” nie wywędrowało z polskiego kontekstu, gdyż jest silnie naznaczone przekonaniem o jego unikalności. Co więcej, w trakcie swych wędrówek po różnych kontekstach tematycznych dotyczących społeczeństwa polskiego pojęcie to zostało przekształcone, aby służyło jako wytrych, za pomoca którego socjologowie wyjaśniają niepożądane przez nich zjawiska.

\section{/// 2. Stefan Nowak i pojęcie próżni socjologicznej}

Stefan Nowak (1924-1989) był jednym z czołowych polskich socjologów. Jego kariera akademicka przypadała na okres komunizmu: 
rozpoczął studia w 1946 roku, przez długi czas kierował Zakładem Metodologii Badań Socjologicznych w Instytucie Socjologii na Uniwersytecie Warszawskim, w latach 1976-1983 był przewodniczącym Polskiego Towarzystwa Socjologicznego. Jest uznawany za ojca polskiej socjologii ankietowej. Jako badacz podejmował przede wszystkim problematykę wartości i postaw oraz ich międzypokoleniowej transmisji (Grabowska, Sułek 1992, Sułek 1998). W latach 70. i 80. był niewątpliwie liderem warszawskiego środowiska socjologicznego, a jego uczniowie pełnią obecnie prominentne funkcje.

W 1979 roku podczas sesji Komitetu Polskiej Akademii Nauk „Polska 2000” zaprezentował swoje spostrzeżenia na temat „próżni socjologicznej” w polskim społeczeństwie ${ }^{2}$. Treść tego wystąienia została dwukrotnie wydrukowana po polsku, najpierw jako esej Przekonania i odczucia wspótczesnych (Nowak 1979a), a następnie jako artykuł w „Studiach Socjologicznych" pod tytułem System wartości społeczeństwa polskiego (Nowak 1979b). Ta ostatnia wersja uzyskała największą liczbę odniesień i dlatego traktuje ja jako kanoniczną. Rok później w „The Polish Sociological Bulletin" ukazał się przekład eseju na język angielski (Nowak 1980). W 1981 roku na fali zainteresowania wydarzeniami w Polsce Nowak powtórzył swoją tezę w czasopiśmie „Scientific American” w artykule zatytułowanym Values and Attitudes of Polish People (1981). Zdaniem Nowaka:

[...] pomiędzy poziomem grup pierwotnych a poziomem narodowej społeczności istnieje - z punktu widzenia identyfikacji ludzi i ich emocjonalnego zaangażowania - rodzaj próżni socjologicznej. Gdybyśmy chcieli naszkicować gigantyczny „socjogram” oparty na ludzkich poczuciach grupowej więzi i identyfikacji, to tak pojęta społeczna struktura naszego kraju jawiłaby się jako „federacja” grup pierwotnych, rodzin i grup opartych na przyjaźni, zjednoczonych w narodowej wspólnocie z bardzo słabymi innymi typami więzi pomiędzy tymi dwoma poziomami (Nowak 1979b: 160).

\footnotetext{
${ }^{2}$ Nie była to pierwsza prezentacja tezy. Podczas V Zjazdu Socjologicznego w 1977 roku Nowak zwrócił uwagę, iż „istnieje, jak się wydaje, w naszym społeczeństwie niepokojąca pustka” (Nowak 1979c: 30). Jednak to w roku 1979 teza została bezpośrednio sformułowana przez Nowaka i stanowiła główny temat jego referatu.
} 
Nowak traktował próżnię jako osobliwość polskiego społeczeństwa. Jego zdaniem obiektywna struktura społeczna (zwłaszcza instytucjonalna) była rozwinięta tak samo jak w innych krajach uprzemysłowionych, natomiast subiektywna struktura społeczna oparta na identyfikacjach jednostek jest szczególna dla Polski. Nowak traktował tę osobliwość jako problematyczną: polskiemu społeczeństwu czegoś brakowało. Brak identyfikacji z poziomem instytucji pośrednich wyjaśniał, wskazując na wyalienowanie od nich. Ludzie nie tworzyli wokół instytucji grup społecznych i mimo uczestnictwa w nich nie myśleli o sobie w kategoriach „my”.

Poza tym, Nowak zaproponował w swoim eseju rozróżnienie na świat ludzi i świat instytucji; podkreślił, że rozproszenie uznawanych wartości wśród członków społeczeństwa miało charakter „losowy” - nie było możliwości odtworzenia jego związku z różnicami w strukturze społecznej; stwierdził również, że religia nie ma w Polsce znaczenia grupotwórczego, ale jedynie odgrywa rolę filozofii prywatnej. Konkluzje te zostały wywiedzione $z$ badań kwestionariuszowych na temat międzypokoleniowego przekazu wartości przeprowadzonych w Warszawie i Kielcach w latach 1972-1974 (Nowak 1989: 8-9). Teza o „próżni socjologicznej” została sformułowana niedługo przed strajkami w sierpniu 1980 roku i powstaniem Solidarności. Nowak i jego uczniowie zaangażowali się w jej działalność, a teza o próżni społecznej stała się tematem dyskusji wykraczających poza socjologię. Na przykład Bronisław Geremek (1981), przewodniczący komisji programowej podczas I Zjazdu NSZZ Solidarność, odwołał się do próżni jako kontekstu, w którym budowana miałaby być „Samorządna Rzeczpospolita". Reagując na bieżące wydarzenia, Nowak sugerował, że Solidarność przyczynia się do zapełnienia próżni.

Wraz z publikacją anglojęzycznej wersji eseju teza o próżni stała się dostępna dla badaczy spoza Polski. Cyrkulowała przede wszystkim w obrębie nauk społecznych. Jak stwierdził Antoni Sułek, „ta sugestywna choć kontrowersyjna hipoteza jest jedną z tych idei, które zadomowiły się w powszechnej socjologii" (1998: 171). Jak wiadomo, często powtarzane koncepcje zaczynają szybko żyć własnym życiem. Następuje ich dekontekstualizacja i oderwanie od pierwotnych intencji autora. Teza o próżni socjologicznej była przywoływana zarówno po śmierci jej autora, jak i po upadku systemu komunistycznego. Bywa powtarzana w zmienionym brzmieniu lub z użyciem innych określeń: pustka społeczna, próżnia społeczna etc. To ostatnie chyba lepiej oddawałoby intencję autora, który mówił o nieobecności czegoś w społeczeństwie. Brzmiąca bardziej uczenie „próżnia socjologiczna" u wielu osób może budzić skojarzenie raczej z brakiem 
czegoś w obrębie socjologii: brakiem zainteresowania pewną tematyką lub luką w teorii.

Mimo błyskawicznego przełożenia koncepcji na język angielski zadomowiło się przekonanie, że próżnia socjologiczna jest osobliwościa polskiego społeczeństwa. Uznano ją zatem za charakterystykę konkretnego przypadku cieszącego się na początku lat 80 . XX wieku sporym zainteresowaniem. Nowak nie miał ambicji tworzenia uniwersalnej koncepcji socjologicznej, lecz chciał scharakteryzować społeczeństwo polskie i wskazać na jego unikalne cechy. Nie próbował również przenosić swojej tezy na inne społeczeństwa bloku socjalistycznego. Interesowało go i niepokoiło to, co dostrzegł w danych na temat identyfikacji Polaków i co pozwoliło mu wyartykułować swoje intuicje na temat rzeczywistości, w której przyszło mu funkcjonować.

\section{/// 3. Metoda}

Zidentyfikowałem 190 publikacji odwołujących się do „próżni socjologicznej”3. Wyselekcjonowałem je spośród wszystkich prac cytujacych teksty Nowaka, w których stawiał on tezę o „próżni socjologicznej” (1979a, 1979b, 1980, 1981). Baza publikacji została uzupełniona o prace, w których nie pada bezpośrednie odwołanie do żadnego z tekstów Nowaka, oraz o prace nieindeksowane przez internetowe wyszukiwarki bibliograficzne. Z pewnością nie jest to baza zawierająca wszystkie prace odnoszące się do pojęcia „,próżni socjologicznej”, jednak zachowana staranność pozwala stwierdzić, że dotarłem do ich zdecydowanej większości i umknąć mi mogły tylko publikacje o bardzo lokalnym zasięgu.

W trakcie analizy treści publikacji odwołujących się do koncepcji „próżni socjologicznej” nadawałem kategorie kodowe kontekstom tematycznym, w których próżnia była przywoływana; statusowi przypisywanemu tej koncepcji (czy była traktowana jako fakt czy podważano jej prawdziwość); sposobowi jej rekonstrukcji (czy następowały przesunięcia jej znaczenia lub przywołania częściowe); oraz cechom samych publikacji, takim jak: język, pochodzenie autora, data publikacji itd. Jest to zatem praca z zakresu analizy dyskursu, gdyż uwzględniane są nie tylko właściwości tekstowe analizowanych treści, ale również ich właściwości

\footnotetext{
${ }^{3}$ W bibliografii niniejszego artykułu wymieniam tylko te z nich, do których bezpośrednio się odwołuję. Bieżąco aktualizowany spis publikacji odnoszących się do tezy o „próżni socjologicznej” dostępny jest w internecie pod adresem: http://mikolajpawlak.bio.uw.edu.pl/research/sociological-vacuum/bibliography-sociological-vacuum/.
} 
pozatekstowe. Od historii idei uprawianej w sposób klasyczny odróżnia ją to, że do analizy nie zostały wybrane teksty uznane za najważniejsze, lecz wszystkie dostępne.

\section{/// 4. Wędrówki „próżni socjologicznej”}

Wśród 190 publikacji przywołujących pojęcie „próżni socjologicznej” z oczywistych względów dominują te w języku polskim - jest ich 113. Ponadto 70 prac powstało w języku angielskim, pięć w niemieckim i po jednej po hiszpańsku i słoweńsku. Jednak większość prac napisanych w językach innych niż polski jest autorstwa badaczy pochodzących lub mieszkających na stałe w Polsce. Natomiast 26 publikacji zostało napisanych przez autorów pierwotnie z Polską niezwiązanych. Najważniejsze konteksty tematyczne, w których pojawia się pojęcie „próżni socjologicznej” to powstanie Solidarności (35 publikacji), społeczeństwo obywatelskie (53), kapitał społeczny (30) oraz jakość demokracji (23).

\section{/// 4.1 Polska widziana z zewnątrz}

Zdecydowana większość publikacji autorów spoza Polski odnoszących się do tezy Nowaka (19) traktuje próżnię socjologiczną jako jedną z charakterystyk naszego społeczeństwa. W kontekstualizacjach bardziej szczegółowych analiz przywoływana jest silna więź łącząca Polaków z rodziną i narodem oraz brak więzi z grupami szczebla pośredniego. Zarysowuje się w ten sposób pewna historia społeczna Polski, której punktami zwrotnymi są krótki i intensywny okres „karnawału" Solidarności 1980-1981 oraz upadek komunizmu w 1989 roku. Przed 1980 rokiem panować miała w Polsce „próżnia socjologiczna”. Ten sposób odniesienia do koncepcji Nowaka jest przejęty z literatury polskiej: zagraniczni badacze, jeśli znają język polski, odwołuja się zwykle do kanonicznego Systemu wartości społeczeństwa polskiego (Nowak 1979b), w innych wypadkach korzystaja z pracy Values and attitudes of Polish people (Nowak 1981) lub do tezy dotarli za pośrednictwem prac innych autorów.

Na szczególną uwagę zasługują prace Janine R. Wedel (1992, 1998), amerykańskiej antropolożki, która w latach 80 . XX wieku prowadziła w Polsce badania dotyczące życia codziennego. Książka pod jej redakcja The Unplanned Society (Wedel 1992) to, jak Wedel deklaruje we wprowadzeniu, próba zaprzeczenia tezie Nowaka. Amerykańska badaczka do- 
wodzi, że próżnię w Polsce lat 80. wypełniał ogrom aktywności społecznych, których nie mogły uchwycić kwestionariuszowe techniki badawcze ugruntowane w pozytywistycznym paradygmacie nauk społecznych. Wedel przytacza wiele przykładów zbiorowej aktywności o sieciowym charakterze. Za najważniejsze uznała działalność „środowisk” - nieformalnych grup społecznych opartych na wzajemnym zaufaniu i o szerszym zasięgu niż rodzina czy grupa przyjaciół, które umożliwiały wymianę dóbr i informacji. Natomiast w ksiazżce Collision and Collusion poświęconej analizie wsparcia przez Zachód budowy demokracji w Europie Wschodniej, Wedel pokazuje, że wbrew wyobrażeniom amerykańskich i europejskich donatorów w Europie Wschodniej już w okresie komunizmu istniały zalążki społeczeństwa obywatelskiego (1998). Takie postrzeganie społeczeństw Europy Wschodniej było wzmacniane, zdaniem Wedel, również przez pochodzących z tego regionu intelektualistów, którzy utrzymywali, że komunizm stłamsił społeczeństwo obywatelskie i należy dopiero rozpocząć jego budowę. Koncepcja „próżni socjologicznej” zostaje przytoczona jako przykład tej tendencji dotyczącej Polski. Paradoksalnie, do rozpowszechniania wiedzy o „próżni socjologicznej” przyczyniła się w dużej mierze sama Wedel i to za jej pośrednictwem przywoływana jest teza Stefana Nowaka jako coś specyficznie polskiego. Pojęcie to wywędrowało z Polski, jednak tylko po to, by służyć do jej opisu.

\section{/// 4.2 Próby przeniesienia próżni socjologicznej do innego obszaru}

W pięciu z 190 publikacji pojęcie „próżni socjologicznej” odnoszone jest do innych społeczeństw niż polskie. Za każdym razem dopasowywane jest do warunków występujących w innych krajach Europy Wschodniej lub traktowane jest jako dotyczące całego regionu. Autorzy wskazuja z reguły na wpływ ustroju socjalistycznego na powstawanie „próżni”.

Gregor Tomc (1991) w analizach, które dotyczyły wpływu ustroju komunistycznego na strukturę społeczeństwa słoweńskiego, wspomina próżnię socjologiczna jako wynik charakterystycznego dla Polski braku organizacji średniego szczebla lub wyobcowania z nielicznych organizacji tego typu. Jego zdaniem, podobnie jak w Polsce i Czechosłowacji, w Słowenii klasy społeczne nie stanowiły o podziale krystalizującym strukturę społeczna. Próżnia socjologiczna w pewnym sensie miała- 
by oddawać także stan społeczeństwa słoweńskiego lat 80 . XX wieku, o którym Tomc gromadził swoje dane ilościowe.

Węgierski socjolog Rudolf Andorka (1995a, 1995b) przywoływał natomiast koncepcję Nowaka w kontekście opisu społeczeństw socjalistycznych jako represjonujących wszelkie grupy i stowarzyszenia pomiędzy rodziną a wspólnotą narodowa. Jego zdaniem społeczne kontakty Węgrów ograniczały się do bliskich krewnych, przyjaciół i kolegów z pracy. Na podstawie analizy budżetów czasu stwierdził, że w socjalistycznym społeczeństwie węgierskim obciążenie pracą zarobkową było tak duże, iż uniemożliwiało pielęgnowanie innych kontaktów społecznych.

Finn Sivert Nielsen (2007) odwoływał się do koncepcji próżni socjologicznej w pracy dotyczącej związku rosyjskiej tożsamości narodowej z projektem budowy państwa sowieckiego. Za Wedel (1992) wskazywał, iż zarówno w sowieckiej Rosji, jak i w Polsce „próżnia” wypełniana jest przez nieformalne sieci kontaktów. Odwołanie do pojęcia próżni socjologicznej było autorowi potrzebne do pokazania, że ustrój socjalistyczny wpływa na prywatyzację życia społecznego i oderwanie go od formalnych struktur.

Alexander Tymczuk, inny pochodzący z Norwegii antropolog, przykładał koncepcję „próżni socjologicznej” do sytuacji na Ukrainie (2005). Również odwołując się do pracy Wedel (1992), wskazywał, że różnego rodzaju ulotne struktury nieformalne wypełniają próżnię socjologiczna w społeczeństwach postkomunistycznych. Są to głównie relacje patron-klient, błat oraz relacje w obrębie danego środowiska.

Również dzięki Wedel (1998) pojęcie „próżni socjologicznej” pojawiło się wśród teoretycznych narzędzi pomagających zrozumieć społeczeństwo postkomunistycznej Serbii w pracy Théodory Vetty (2009) dotyczącej roli organizacji pozarządowych w budowie tamtejszej demokracji. Pochodząca z Grecji autorka pokazywała, jak ruchy społeczne lat 70. i 80. XX wieku przyczyniły się do wypełniania „próżni” wytwarzanej przez komunistyczne państwo. Ich spadkobiercami byli, zdaniem autorki, działacze serbskich organizacji pozarządowych.

W jaki sposób pojęcie próżni socjologicznej dotarło do posługujących się nim autorów? Andorka jeszcze w latach 70. współpracował z polskimi badaczami, którym z pewnością było ono znane. Natomiast trójka antropologów odwołała się do prac Wedel. Warto jednak zauważyć, że Wedel zakwestionowała istnienie „próżni socjologicznej” w rozumieniu Stefana Nowaka. Uważała bowiem, że próżnia ta jest za- 
pełniana przez struktury nieformalne. Można powiedzieć, że amerykańska badaczka dokonała modyfikacji oryginalnej koncepcji. Dlatego badacze, którzy poznali dzięki Wedel pojęcie „próżni socjologicznej”, rozumieli ja jako pustkę między makrostrukturą a rodzina, która w warunkach socjalistycznych zostaje zapełniona przez powiązania nieformalne. W efekcie tego przekształcenia pojęcie Nowaka przestało służyć do opisu statycznego stanu struktury tych społeczeństw, ale posłużyło do oddawania ich dynamiki: komunistyczne państwa wywierały presje tworząca ,próżnię”, którą zapełniały oddolne działania zbiorowe o nieformalnym charakterze.

Zupełnie inny charakter miała próba przeniesienia pojęcia „próżni” z polskiego gruntu za granicę dokonana przez Mikołaja Cześnika (2008b). Posługując się danymi dotyczącymi zachowań wyborczych, zmierzył on poziom ,próżni socjologicznej” w 35 krajach uprzemysłowionych. Jego celem było rozprawienie się z przyjmowanym przez wielu krajowych autorów założeniem, iż próżnia socjologiczna jest przyczyną niskiej jakości demokracji w Polsce. Analizy Cześnika pokazują, że nie ma korelacji między „próżnią socjologiczną” (operacjonalizowaną jako niski poziom identyfikacji z grupami pośrednimi) a indeksami jakości demokracji. Co więcej, istnieją społeczeństwa, w których mierzony za pomocą dostępnych danych poziom „próżni socjologicznej” jest wyższy niż w Polsce. To jedyny przypadek analizy porównawczej dotyczącej tego pojęcia. Prowadzi on jednak do znaczącej konkluzji, iż postrzeganie próżni socjologicznej jako polskiej osobliwości nie ma podstaw. Analizy Cześnika nie przeniosły pojęcia „próżni” poza polski kontekst. Obnażył on jednak, przyjmowane od czasu Nowaka za oczywiste, myślenie o „próżni” jako czymś szczególnym dla naszego społeczeństwa.

\section{/// 4.3 Porównanie z podobnymi koncepcjami}

Wśród koncepcji zbliżonych do „próżni socjologicznej” Nowaka, które zyskały pewną popularność w naukach społecznych, na uwagę zasługuje przede wszystkim teza postawiona przez Williama Kornhausera (1960: 58) mówiąca o załamywaniu się społeczności (loss of community). Kornhauser dowodził, iż społeczności pośredniczące między makrostruktura a jednostką zanikają zarówno w zachodnich społeczeństwach masowych, jak i w należących do bloku sowieckiego społeczeństwach totalitarnych. W jego ujęciu, łatwiej jest sterować jednostkami, które 
nie grupują się we wspólnoty średniego zasięgu, dlatego umasowienie społeczeństw po obu stronach żelaznej kurtyny osłabiało szanse dla demokratycznych rządów: jednostka zmagać się musiała z całościowością swojego państwa.

Z kolei Richard Rose (1995) w analizach rosyjskiej demokracji tuż po upadku komunizmu użył określenia „,społeczeństwo klepsydry” (hour-glass society). U jego podstaw toczyć się miało bogate życie przejawiające się w silnych nieformalnych sieciach zaufania między przyjaciółmi i krewnymi oraz polegające na aktywności małych grup. Na górze społeczeństwa klepsydry z kolei toczyć się miało intensywne życie polityczne, w którym elity rywalizują o władzę, bogactwo i prestiż. Jednak kontakty między dołem a górą są bardzo ograniczone - jak w szyjce klepsydry. W związku z tym nie ma w Rosji, zdaniem Rose’a, wspólnoty obywatelskiej. Klepsydrowość rosyjskiego społeczeństwa jest korzystna dla elit, bo utrudnione jest ich oddolne kontrolowanie, ale paradoksalnie chroni również zwykłych członków społeczeństwa przed zbytnią kontrolą ze strony państwa. Dają oni sobie radę w życiu nie dzięki państwu, ale też nie przeciw niemu, a obok niego, wykorzystując nieformalne sieci. Metaforę Rose’a przykładano również do innych społeczeństw środkowoeuropejskich, w tym do społeczeństwa polskiego. Stawiano ją obok koncepcji próżni socjologicznej (zob. Lasinska 2013). Mimo pewnego podobieństwa (brak struktur pośredniczących) dotyczą one jednak innego zjawiska. Teza Nowaka mówi o identyfikacjach z grupami pierwotnymi i z narodem, natomiast koncepcja Rose’a o słabości mechanizmów pośredniczących między masami a elitami.

Ostatni przykład spojrzenia z zachodu na Europę Wschodnią, w którym znajdziemy podobny pomysł do tezy Nowaka, to „,podejście braku środka" (missing middle approach) zidentyfikowane przez Geoffreya Evansa i Stephena Whitefielda (1993). Po upadku komunizmu brytyjscy badacze postanowili odpowiedzieć na pytanie dotyczące uwarunkowań powstania stabilnych systemów partyjnych w Europie Wschodniej. Dokonując przeglądu literatury, wyodrębnili trzy podejścia do wyjaśniania sposobu kształtowania się systemów partyjnych: podejście modernizacyjne, podejście braku środka oraz podejście porównawczego komunizmu. To ostatnie uważali za najwłaściwsze, bo umożliwiające uwzględnienie uwarunkowań historycznych i instytucjonalnych poszczególnych krajów regionu, których większość, ich zdaniem, znajdowała się gdzieś pomiędzy brakiem środka a modernizacją. Teza o brakującym środku przyjmuje, iż w krajach Europy Wschodniej brak mezostruktur, dzię- 
ki którym interesy mogłyby być artykułowane inaczej niż na poziomie całego państwa lub narodu. W konsekwencji uniemożliwione jest powstanie trwałych podziałów politycznych, a więc i stabilnego systemu politycznego (Evans, Whitefield 1993: 528-529). Rekonstruując podejście brakującego środka, brytyjscy politolodzy odwoływali się między innymi do polskich badaczy, takich jak: Lena Kolarska-Bobińska, Marek Ziółkowski, Mirosława Marody i Jadwiga Koralewicz. Autorzy ci dobrze znali tezę Nowaka i odwoływali się do niej w swoich pracach i, co należy podkreślić, tworzyli w klimacie naukowym, w którym traktowana była ona jako jedno z ważniejszych twierdzeń o polskim społeczeństwie. Można zatem zaryzykować przypuszczenie, że w pośredni sposób teza Nowaka przyczyniła się do sformułowania przez Evansa i Whitefielda podejścia brakującego środka. Nie wolno jednak zapominać, iż brytyjscy autorzy uważali Polskę obok Czech i Węgier za państwo, w którym następuje intensywne zapełnienie brakującego środka i do opisu kształtującego się w nim systemu partyjnego najlepiej pasuje podejście modernizacyjne, mówiące, że struktura społeczna upodabnia się tutaj do struktury społeczeństw zachodnich i w związku z tym wykształca się charakterystyczny dla nich stabilny system partyjny (Evans, Whitefield 1993: 541).

\section{/// 4.4 Zastosowanie tezy Nowaka w Polsce}

Cztery najważniejsze konteksty tematyczne, w których pojęcie „próżni socjologicznej” jest wykorzystywane w naukach społecznych, to: powstanie ruchu Solidarność, społeczeństwo obywatelskie, kapitał społeczny oraz kondycja demokracji (Pawlak 2015). W niniejszym artykule spróbuję spojrzeć na wędrówkę pojęcia zaproponowanego przez Nowaka między tymi polami problemowymi.

Teza o próżni socjologicznej została ogłoszona na rok przed protestami robotniczymi, które w 1980 roku doprowadziły do powstania Solidarności. Wydarzenia te były dla polskich socjologów zaskoczeniem, ponieważ za pomocą technik sondażowych nie byli w stanie przewidzieć siły społecznej mobilizacji (Sułek 2011). Cześć autorów uznała, że wydarzenia z początku lat 80. są dowodem błędności tezy Nowaka. Antoni Z. Kamiński (1992: 253) wskazywał na pominięcie roli Kościoła katolickiego jako organizacji podtrzymującej więzi zaufania i wspólnoty. Witold Morawski (2010) i Andrzej Rychard (2010) zwracali uwage na niewystarczające uwzględnienie 
znaczenia zakładów pracy. Inni autorzy, na przykład uczeń Nowaka Ireneusz Krzemiński (1992, 2013), wskazywali na konieczność uwzględnienia dodatkowych głębszych struktur subiektywnych (takich jak metapostawy czy pragnienie realizacji wartości moralnych). Jak sądzę, dyskusja o próżni socjologicznej, którą wywołało powstanie Solidarności, przyczyniła się do popularyzacji samego pojęcia. Próżnia przestała być stałą cechą społeczeństwa polskiego, ale okazało się, że pod pewnymi warunkami, na co zwrócił sam Nowak (1981: 53), może zacząć się zapełniać. Otworzyło to drogę do dociekań na temat tego, w jakich warunkach coś może wypełnić „próżnię socjologiczną".

Propozycją wypełnienia próżni socjologicznej stało się społeczeństwo obywatelskie, którym polskie nauki społeczne zaczęły się interesować pod koniec lat 80., co było ściśle powiązane z doświadczeniem Solidarności i opozycji antykomunistycznej (Załęski 2010). Tym, co rzuca się w oczy przy lekturze prac na temat społeczeństwa obywatelskiego, w których wykorzystane jest pojęcie „próżni socjologicznej”, jest rozczarowanie autorów jego kondycją w Polsce. Mowa na przykład o barierach (Bukowski, Gadowska, Polak 2008, Dzwończyk 2003), blokadach (Szczegóła 2003) lub czynnikach ograniczających jego rozwój (Dzwończyk 2005) lub też o społecznym bezruchu (Nowak, Nowosielski 2005). Stan „próżni socjologicznej” wymieniany jest jako przyczyna owych przeszkód.

Podróży idei zwykle towarzyszy jej transformacja (Czarniawska 2010). Tak też dzieje się z pojęciem próżni socjologicznej, gdy pojawia się w kontekście problematyki społeczeństwa obywatelskiego. Próżnia socjologiczna przestaje być rozumiana jako brak identyfikacji z grupami poziomu pośredniczącego między rodziną a narodem; następuje przesunięcie znaczenia i pojęcie to zaczyna oznaczać słabość lub wręcz brak grup poziomu mezo. Nowak wskazywał na to, że obiektywna struktura społeczna w Polsce jest podobna do struktur innych społeczeństw uprzemysłowionych (1979: 160), jej niepokojąca osobliwością był brak identyfikacji ze strukturami pośrednimi. Natomiast w rozważaniach o społeczeństwie obywatelskim, w którym struktury pośrednie mają umożliwiać działanie zbiorowe, pojęcie ukute w latach 70. XX wieku traktuje się jako opisujące brak lub wyraźna słabość tych struktur. Intuicja mówiąca o tym, że gdy grupa społeczna nie stanowi obiektu identyfikacji, ma mniejszą zdolność do działania jako aktor zbiorowy, wydaje się zdroworozsądkowa. Jednak w rozważaniach dotyczących społeczeństwa obywatelskiego w Polsce nie jest ona poddawana refleksji ani testowaniu, lecz przyjmowana jako oczywistość. 
Kolejny temat, w którym przywoływane jest pojęcie „próżni socjologicznej”, to kapitał społeczny; termin wprowadzony do światowej socjologii w latach 80. dzięki pracom Jamesa Colemana (1988) i Pierre’a Bourdieu (1986), a spopularyzowany w Polsce w dużej mierze dzięki ujęciu Putnama (1995). W większości publikacji jest on rozumiany za Robertem D. Putnamem (1995) jako zasób pewnej zbiorowości. Temat ten łączy się zatem z problematyką społeczeństwa obywatelskiego: w ujęciu Putnamowskim duży kapitał społeczny jest warunkiem sprawnie funkcjonującego społeczeństwa obywatelskiego. Pojęcie „próżni społecznej” przydaje się również do rozróżnienia na kapitał wiążący i pomostowy (Putnam 2008). Ten pierwszy ma łączyć przedstawicieli jednej grupy - silna identyfikacja z rodziną, a ten drugi łączyć przedstawicieli różnych grup - brak identyfikacji pośrednich u Nowaka. Znów pojęcie przeniesione do innego kontekstu zostaje przetworzone tak, aby do niego pasować. Zauważmy, że w tej interpretacji pominięta zostaje część tezy Nowaka mówiąca o silnej identyfikacji z narodem. Podobnie jak prace dotyczące społeczeństwa obywatelskiego i te na temat kapitału społecznego zawieraja pesymistyczny ton. Anna Kubiak i Anita Miszalska (2004) mówiły o atomizacji społeczeństwa i deficycie więzi horyzontalnych, a Janusz Czapiński (2006) ogłosił wręcz brak społeczeństwa w państwie polskim. „Próżnia socjologiczna” przydaje się autorom do wyjaśniania zjawisk, które oceniają negatywnie, jednak spekulacja i żonglerka pojęciami dominują w ich tekstach. Na mocy tej samej retoryki mogliby przekonywać, iż silna identyfikacja z narodem jest podłożem do wytwarzania się społecznego kapitału o typie pomostowym, jednak „próżnia socjologiczna” potrzebna jest im do opisu zjawisk ocenianych negatywnie, więc ten aspekt koncepcji Nowaka zostaje pominięty w ich rozważaniach.

„Próżnia socjologiczna” zawędrowała również do pola analiz dotyczących kondycji polskiej demokracji. Tutaj traktowana była jako ograniczenie dla wykształcenia się elektoratów partyjnych (Grabowska 2004: 163), przyczyna słabości systemu partyjnego (Kubiak 1999), przestrzeń umożliwiająca penetrowanie polskiego życia politycznego przez siły antyrozwojowe (Zybertowicz 2009) czy inspiracja do ukucia nowego pojęcia „próżni politycznej”, w której elity poprzez słabość instytucji i aktorów lokalnego życia politycznego nie mają odpowiedniej komunikacji z masami (Wasilewski 2006: 16). W tym polu dociekań wyróżniają się przywołane wcześniej prace Cześnika, który wykazał, iż nie ma ani teoretycznych (2008a), ani empirycznych (2008b) powodów, by uważać „próżnię socjologiczna”” za przeszkodę w funkcjonowaniu demokracji. 


\section{/// 5. Wnioski}

Pojęcie „próżni socjologicznej”, będąc jednym z częściej używanych oryginalnych wytworów polskiej socjologii, nie wywędrowało poza krajowy kontekst. Do zrobienia międzynarodowej kariery miało z pewnościa dobre warunki wyjściowe: prace Nowaka zostały bardzo szybko ogłoszone po angielsku, a sprawy społeczeństwa polskiego cieszyły się na początku lat 80. dużym zainteresowaniem na świecie. Zarówno zagraniczni, jak i rodzimi badacze posługują się wprowadzonym przez Nowaka pojęciem, ale właściwie wyłącznie w odniesieniu do społeczeństwa polskiego. Pojawiło się tylko kilka prób odniesienia pojęcia próżni socjologicznej do innych społeczeństw Europy Wschodniej. „Próżnia” nie stała się jednak pojęciem, dzięki któremu można by próbować opisywać społeczeństwa innych regionów Europy i świata. Stała się pojęciem zaświadczającym o polskiej unikalności.

Paradoksalnie, próżnia nie mogła odbyć dalekiej podróży, ponieważ od początku była traktowana jako cecha szczególna polskiego społeczeństwa. To dlatego zyskała tak dużą popularność w kraju i za granica. Próżnia przedstawiana jest do dzisiaj jako coś wyjątkowego, jako fatum ciążące nad polskim społeczeństwem, a socjologów w Polsce dręczy horror vacui - syndrom strachu przed próżnia (Pawlak 2015). Uderzające jest jednak to, że założenie o polskiej specyfice pojęcia „próżni socjologicznej” zostało przyjęte całkowicie na wiarę. Nikt z wyjątkiem przywoływanego wyżej Cześnika (2008b) nie próbował sprawdzać, czy podobnego rozkładu identyfikacji nie ma w innych społeczeństwach.

Śledząc wędrówkę pojęcia „próżni socjologicznej” między polami badawczymi, można również zaobserwować, jak zmieniają się w polskiej socjologii ogólniejsze ramy ich ujmowania. Nowak mówił o identyfikacjach z grupami i problematyce więzi społecznych, która obecnie bardzo często przedstawiana jest z użyciem terminologii kapitału społecznego. Natomiast działanie zbiorowe, o którym Nowak mówił w języku grup społecznych, obecnie często opisywane jest słownictwem pochodzącym z różnorakich koncepcji społeczeństwa obywatelskiego.

Od ponad 35 lat pojęcie „próżni socjologicznej” jest naginane tak, aby pasowało do potrzeb autorów używających go do opisu i zrozumienia innych zjawisk niż te, dla których zostało pierwotnie ukute. W tego typu transformacjach nie ma nic nadzwyczajnego. Jednak modyfikacje tezy Nowaka należy w bardzo wielu przypadkach ocenić negatywnie. Służą one często do wyjaśnienia zjawisk jednostronnie przedstawianych przez auto- 
rów, dramatyzujących swoje opisy kondycji społeczeństwa obywatelskiego czy poziomu kapitału społecznego w Polsce. Nowakowi przypisuje się twierdzenie o braku struktur, a nie o braku identyfikacji ze strukturami. Często zapominany jest również komponent jego tezy mówiący o silnej identyfikacji z narodem, zwłaszcza gdy próżnia socjologiczna przywołana zostaje do opisu rozpadu więzi czy stanu anomii itp. Istnienie „próżni socjologicznej” traktowane jest jako fakt. Najbardziej zaskakuje jednak, że pojęcie to nie pojawia się w pracach dotyczących struktury społecznej. Jest to pole badawcze o dużej tradycji w polskiej socjologii i przecież Nowak, mówiąc o próżni socjologicznej, dokonywał analizy subiektywnej struktury społecznej.

„Próżnia socjologiczna” poprzez swoje wędrówki stała się niestety pojęciem wytrychem, które nie pomaga zrozumieć zjawisk zachodzących w polskim społeczeństwie. Pojęcie to jednak nie wywędrowało właściwie poza kontekst Polski i nadal służy do argumentowania, często w bardzo dramatycznym tonie, o rzekomej unikalności tutejszej rzeczywistości społecznej.

Bibliografia:

/// Andorka R. 1995a. Hungarian Society: Heritage of the Past, Problems of the Transition and Possible Future Development up to 2005, „Társadalom és gazdaság Közép- és Kelet-Európában / Society and Economy in Central and Eastern Europe", nr 17(1), s. 7-74.

/// Andorka R. 1995b. Changes in Hungarian Society Since the Second World War, „Macalester International”, nr 2, s. 114-133.

/// Bourdieu P. 1986. The Forms of Capital, [w:] Handbook of Theory and Research for the Sociology of Education, red. J.G. Richardson, Greenwood Press, s. 241-258.

/// Bukowski A., Gadowska K., Polak P. 2008. Bariery w dystrybucji środkón unijnych a mechanizmy systemowe w (schytkowym) państwie bezpieczeñ́stwa socjalnego. Praypadek Polski, „Studia Socjologiczne”, nr 1(188), s. 5-43.

/// Coleman J.S. 1988. Social Capital in the Creation of Human Capital, „A American Journal of Sociology", nr 94 (Supplement), s. S95-S120.

/// Czapiński J. 2006. Polska - państwo bez społeczeństwa, „Nauka”, nr 1, s. 7-25. 
/// Czarniawska B. 2010. Troche inna teoria organizacji. Organiæowanie jako konstrukecja sieci driałan, Poltext.

/// Cześnik M. 2008a. Próżnia socjologiczna a demokracja. Przykład postkomunistycznej Polski, „Kultura i Społeczeństwo”, nr 52(4), s. 19-50.

/// Cześnik M. 2008b. Próżnia socjologicz̨na a demokracja - analizy empiryczne, „Studia socjologiczne”, nr 2(189), s. 5-28.

/// Dzwończyk J. 2003. The Barriers for the Development of Civic Society in Poland after 1989, „Polish Political Science”, nr 32, s. 117-125.

/// Dzwończyk J. 2005. Czynniki ograniczajace rozwój spoteczeństwa obywatelskiego w Polsce po 1989 roku, „Zeszyty Naukowe/Akademia Ekonomiczna w Krakowie", nr 692, s. 63-76.

/// Evans G., Whitefield S. 1993. Identifying the Bases of Party Competition in Eastern Europe, „British Journal of Political Studies”, nr 23(4), s. 521-548.

/// Geremek B. 1981. Najgroźniejsza jest apatia, „Tygodnik Solidarność” 30.10.1981, nr 31, s. 6.

/// Grabowska M. 2004. Podziat postkomunistyczny: spoleczne podstawy polityki w Polsce po 1989 roku, Wydawnictwo Naukowe Scholar.

/// Grabowska M., Sułek A. 1992. Stefan Nowak jako badaczspoleczeństwa polskiego, [w:] Driedrictwo Stefana Nowaka, red. A. Sułek, Uniwersytet Warszawski - Instytut Socjologii, Polskie Towarzystwo Socjologiczne, s. 14-29.

/// Kamiński A.Z. 1992. An Institutional Theory of Communist Regimes: Design, Function, and Breakdown, ICS Press.

/// Kornhauser W.A. 1960. The Politics of Mass Society, Routledge and Kegan Paul.

/// Krzemiński I. 1992. Latentne wzory kultury a dynamika postaw społeczeństwa polskiego, [w:] Driedrictwo Stefana Nowaka, red. A. Sułek, Uniwersytet Warszawski - Instytut Socjologii, Polskie Towarzystwo Socjologiczne, s. 105-123.

/// Krzemiński I. 2013. Świat zakorzeniony, [w:] tegoż, Solidarność. Niespetniony projekt polskiej demokracji, Europejskie Centrum Solidarności, s. 209-241.

/// Kubiak A., Miszalska A. 2004. Czy nowa próżnia spoteczna, čyli o stanie więi społecznej w III RP, „Kultura i Społeczeństwo”, nr 48(2), s. 19-43. 
/// Kubiak H. 1999. Parties, Party Systems, and Cleavages in Poland: 1918-1989, [w:] Cleavages, Parties, and Voters: Studies from Bulgaria, the Czech Republic, Hungary, Poland, and Romania, red. K. Lawson, A. Römmele, G. Karasimeonov, Praeger Publishers, s. 77-92.

/// Lasinska K. 2013. Social Capital in Eastern Europe: Poland and Exception?, Springer VS.

/// Morawski W. 2010. Prometeusz spetany?, [w:] Modernizacja Polski. Struktury, agencje, instytucje, red. W. Morawski, Wydawnictwo Akademickie i Profesjonalne, s. 90-123.

/// Nielsen F.S. 2007. The Eye of the Whirlwind: Russian Identity and Soviet Nation-Building. Quests for Meaning in a Soviet Metropolis, Anthrobase.com.

/// Nowak S. 1979a. Præ̨ekonania i odczucia wspótczesnych, [w:] Polaków portret wtasny, red. M. Rostworowski, Wydawnictwo Literackie, s. 122-145.

/// Nowak S. 1979b. System wartości spoleczenstwa polskiego, „Studia Socjologiczne", nr 4(75), s. 155-173.

/// Nowak S. 1979c. Metodologiczne problemy badania przemian spotecznych, [w:] Tendencje rozwoju społecznego, red. E. Krzeczkowska, Główny Urząd Statystyczny, s. 25-37.

/// Nowak S. 1980. Value Systems of Polish Society, „The Polish Sociological Bulletin", nr 50(2), s. 5-20.

/// Nowak S. 1981. Values and Attitudes of Polish People, „Scientific American”, nr 245(1), s. 45-53.

/// Nowak S. 1989. Wstęp, [w:] Ciagtość $i$ żmiana tradycji kulturowej, red. S. Nowak, Państwowe Wydawnictwo Naukowe, s. 5-14.

/// Nowak M., Nowosielski M. 2005. Od „próżni socjologicznej” do „spotecznego bezruchu". Uwarunkowania ewolucji spoteczeństwa obywatelskiego w Polsce lat 80. i 90. XX wieku, [w:] Państwo, samorzad i spoteczności lokalne: Piotr Buczkonski in memoriam, red. K. Bondyra, M.S. Szczepański, P. Śliwa, Wydawnictwo Wyższej Szkoły Bankowej w Poznaniu, s. 267-292.

/// Pawlak M. 2015. From Sociological Vacuum to Horror Vacui: How Stefan Nowak's Thesis is Used in Analyses of Polish Society, „Polish Sociological Review", nr 1(189), s. 5-27. 
/// Putnam R.D. 1995. Demokracja w dzৃiałaniu: tradycje obywatelskie we wspótczesnych Wtoszech, tłum. J. Szacki, Społeczny Instytut Wydawniczy Znak, Fundacja im. Stefana Batorego.

/// Putnam R.D. 2008. Samotna gra w kregle: upadek i odrodzenie wspólnot lokalnych $w$ Stanach Zjednoczonych, tłum. P. Sadura, S. Szymański, Wydawnictwo Akademickie i Profesjonalne.

/// Rose R. 1995. Russia as an Hour-Glass Society: A Constitution without Citizens, „East European Constitutional Review”, nr 4(3), s. 34-42.

/// Rychard A. 2010. System instytucjonalny komunizmu. Jak działat, zmieniat sie i upadt, [w:] Modernizacja Polski. Struktury, agencje, instytucje, red. W. Morawski, Wydawnictwo Akademickie i Profesjonalne, s. 435-460.

/// Sułek A. 1998. Stefan Nowak and Empirical Sociology in Poland, „Polish Sociological Review", nr 122(2), s. 165-176.

/// Sułek A. 2011. O nieprzewidywalności rewolucji. Dlaczego polska socjologia nie przenvidziała „Solidarności”, [w:] tegoż, Obrazy ż̇̇ycia socjologii w Polsce, Oficyna Naukowa, s. 243-265.

/// Szczegóła L. 2003. Blokady społeczeństwa obywatelskiego w Polsce, „Rocznik lubuski”, 29(1), s. 11-26.

/// Tomc G. 1991. Rąredi v socialistični družbi. Primer Slovenije w osemdesetih letih, „Družboslovne razprave”, nr 8(12), s. 118-138.

/// Tymczuk A. 2005. Public Duties and Private Obligations: Networking and Personalisation of Relations in Ukraine, University of Oslo.

/// Vetta T. 2009. „Democracy Building” in Serbia: The NGO Effect, „,Southeastern Europe", nr 33(1), s. 26-47.

/// Wasilewski J. 2006. Wprowadzenie. Elita politycz̨na średniego sžczebla - problematyka badania, [w:] Powiatowa elita polityczna: rekrutacja, struktura, driałanie, red. J. Wasilewski, ISP PAN, s. 9-37.

/// Wedel J.R. 1992. Introduction, [w:] The Unplanned Society. Poland During and After Communism, red. J.R. Wedel, Columbia University Press, s. 1-20.

/// Wedel J.R. 1998. Collision and Collusion: The Strange Case of Western Aid to Eastern Europe 1989-1998, Macmillan. 
/// Załęski P. 2010. Czy Solidarność była społeczeństwem obywatelskim? Jak zostat rapomniany neorepublikeninski projekt samorzqdnej Rzeczypospolitej, „Kultura i Społeczeństwo", nr 54(4), s. 141-152.

/// Zybertowicz A. 2009. Kontrola społeczna trzeciego stopnia, [w:] Idee naukowe Adama Podgóreckiego, red. J. Kwaśniewski, J. Winczorek, IPSiR UW, s. $152-178$.

\section{/// Abstrakt}

Teza Stefana Nowaka o „próżni socjologicznej” to najczęściej przywoływane twierdzenie o polskim społeczeństwie. W artykule przedstawiono, jak za pomocą tego pojęcia spoglądano z zewnątrz na polskie społeczeństwo i jak pojęcie to próbowano odnieść do innych społeczeństw.

„Próżnia socjologiczna” została porównana z podobnymi pojęciami tj. „załamywanie się społeczności”, „,społeczeństwo klepsydry”, ,perspektywa braku środka". W artykule przedstawiono także wędrówkę pojęcia „próżni socjologicznej” pomiędzy czterema polami tematycznymi: Solidarność, społeczeństwo obywatelskie, kapitał społeczny, jakość demokracji.

Pojęcie „próżni socjologicznej” nie wywędrowało poza polski kontekst, gdyż jest silnie naznaczone przekonaniem o jego unikalności. W trakcie swych wędrówek po różnych kontekstach tematycznych zostało tak przekształcone, aby służyło jako pojęcie wytrych, za pomocą którego socjologowie wyjaśniają niepożądane przez nich zjawiska.

Słowa kluczowe:

próżnia socjologiczna, Stefan Nowak, Solidarność, kapitał społeczny, społeczeństwo obywatelskie, jakość demokracji

\section{/// Abstract}

Stefan Nowak's thesis on the sociological vacuum is the most frequently referenced statement on Polish society. This article introduces how Polish society was perceived "from the outside" by the use of the vacuum concept and shows attempts to apply the concept to other societies. The sociological vacuum is compared to other similar concepts: the loss of community, the hourglass society, and the missing middle approach. The concept's travel

\section{/ 334 STANRZECZY 1[10]/2016}


between four domains (Solidarity, civil society, social capital, and the quality of democracy) is presented. The concept of the sociological vacuum has not travelled beyond the Polish context because it is strongly connected to the assumption of Polish uniqueness. During its travels through various thematic domains, the concept transformed, and it is currently a buzzword used to explain phenomena undesired by sociologists.

Keywords:

sociological vacuum, Stefan Nowak, Solidarność, social capital, civil society, quality of democracy 